\title{
Antecedents of Psychological Empowerment in the Malaysian Private Higher Education Institutions
}

\author{
Nik Azida Abd. Ghani \\ Politeknik Kota Bharu, Km24 Kok Lanas, 16450 Kota Bharu, Kelantan, Malaysia \\ Tel: 60-13-9337550_E-mail: nikazida5@yahoo.com \\ Tengku Ahmad Badrul Shah bin Raja Hussin \\ Politeknik Kota Bharu, Km24 Kok Lanas, 16450 Kota Bharu, Kelantan, Malaysia \\ Tel: 60-13-9300198Ｅ-mail: tabs2104@yahoo.com \\ Kamaruzaman Jusoff (Corresponding author) \\ Tropical Forest Airborne Observatory, Faculty of Forestry, Universiti Putra Malaysia \\ Serdang, 43400 Selangor, Malaysia \\ Tel: 60-3-89467176 E-mail: kjusoff@yahoo.com
}

This project is sponsored by Ministry of Education, Malaysia (Sponsoring information)

\begin{abstract}
Psychological empowerment comprising four cognitive dimensions i.e. meaning, competence, autonomy and impact in the context of private higher education institutions is being validated. Five factors considered as antecedents i.e. access to information, resources, organizational support and opportunity to learn and develop, and trust were studied. This study examined on a sample of 312 lecturers from 25 private higher education institutions in three states (Penang, Kedah and Kelantan) in Malaysia. Survey data was analyzed using correlation and regression analyses to assess the relationship among the factors as well as the contribution of each factor to psychological empowerment. The study verifies that psychological empowerment comprised four dimensions as suggested by Spreitzer (1992). The results indicated that all antecedents under study have significant relationship with psychological empowerment at .01 significance level. It has also been found that access to opportunity to learn and develop and access to resources are significant predictors of psychological empowerment. It is recommended that management of higher education institutions use these findings to improve the level of psychological empowerment of lecturers.
\end{abstract}

Keywords: Antecedent, Academia, Private Higher Education, Malaysia

\section{Introduction}

In 1991, the Malaysian government unveiled its Vision 2020, the year by which Malaysia would achieve the status of an industrialized and developed country in terms of its economy, national unity, social cohesion, social justice, political stability, system of government, quality of life, social and spiritual values, national pride and confidence. Under Vision 2020, the liberalization of education policies has caused democratization, privatization and decentralization of Malaysian education system. The development and changes in education make the educational administration and management could not be effectively done at central level. Decentralization also could overcome bureaucracy and enable decisions and actions, especially those that are not related to policy making, carried out at the lower level (Bahagian Perancangan dan Penyelidikan Pendidikan, 1995). Decentralization is difficult to be implemented because the nation's education system is still centralized (Marzita, 2005).

The decentralization of education management system is to promote institution-based management and empowerment of teachers (Lee, 1999). Implementing empowerment, either in education or other institutions, requires certain prerequisites or antecedents to empowerment. For example, work environment that provide access to information, organizational support, resources and opportunity to learn and develop are empowering and enhance employees' power to accomplish work within an organization (Kanter, 1977; 1983). Trust is also a critical condition before management could empower their employees (Mishra \& Spreitzer, 1994).

The practices of empowerment had actually being implemented long ago at all levels in the Malaysian Ministry of Education (Bahagian Perancangan dan Penyelidikan Pendidikan, 1995). The department of Educational Planning and Research has proposed a few aspects that ought to be empowered i.e. managing teaching time, controlling the class, communication and developing relationship with the students according to ways that are considered best and suitable with the curriculum used, students' ability and the environment. An empowered teacher has significant authority in the 
strategy selection process and implementation methods of education policies (Bahagian Perancangan dan Penyelidikan Pendidikan, 1995). Empowerment is defined by the Ministry of Education as 'a professional practice of the educational administration and management'. These empowerment practices include those related to the smooth and efficient implementation of education policy; teachers' and teaching autonomy; and the sharing of power by the leader of the institution with its subordinates (Bahagian Perancangan dan Penyelidikan Pendidikan, 1995).

The concept of empowerment carries different meanings in different contexts (Zimmerman, 1990). Hence, to study the concept of empowerment at the workplace, Spreitzer (1995a) used the intrapersonal concept specifically for workplace as described by Thomas and Velthouse (1990). This psychological perspective of empowerment focuses on the perception of employee on empowerment (Spreitzer, 1995b, 1997; Thomas \& Velthouse, 1990). The level of psychological empowerment experienced could be influenced by geographical location and organizational environment and work (Spreitzer, 1995b). Therefore, the psychological empowerment experienced by lecturers depends on the lecturers' perception of empowerment in their institutions.

Conger and Kanungo (1988) defined psychological empowerment as the process of enhancing the feeling of self-efficacy among the members of an organization through the identification of condition that caused powerlessness and also through the reduction of the powerlessness state. The state of powerlessness can be reduced by giving efficacy information through formal and informal technique of organizational practices (Conger \& Kanungo, 1988). The psychological approach to empowerment focused on the intrinsic motivation and not on the managerial practices that are used to increase the level of power owned by the employees (Dee et. al., 2003).

Psychological empowerment comprises four different cognitive dimensions: meaning, competence, autonomy and impact (Spreitzer, 1995b; Thomas \& Velthouse, 1990). These dimensions reflect the individual orientation towards his task role (Thomas \& Velthouse, 1990) and are the basic core for psychological empowerment in the workplace (Houghton \& Yoho, 2005). Low rating in any dimension will lower overall empowerment. Therefore, higher ratings in all dimensions are needed to ensure a high level of empowerment (Lee \& Koh, 2001). According to Brancato (2006), a worker should understand the dimensions of psychological empowerment and the strategies related to this concept. The administration should examine each dimension and be ready to take actions necessary to increase the level of employee agreement towards the dimensions and increase the level of psychological empowerment experienced by employee (Hancer \& George, 2003). Therefore, the objective of this study is to identify the validity and reliability of the four dimensions of psychological empowerment based on 1992's Spreitzer's theory. This study also examines the relationship between antecedents and psychological empowerment as well as the effect of antecedents on psychological empowerment.

\section{Method and materials}

\subsection{Sampling design}

This cross sectional study utilizing ex-post facto research methodology and correlational in nature is carried out in 25 higher education institutions in three states in Malaysia, i.e. Penang, Kedah and Kelantan. The sample comprised 312 lecturers. The researcher used multi-stage sampling method to select the states, the institutions and respondents. Random sampling method was used to select the institutions from the list provided by the Department of Higher Education Institution (Private) Administration while convenience sampling was used to select the respondents as the researcher did not have any influence in the selection process. Cochran's (1977) sample size formula and finite population adjustment (Lohr, 1999) was used to determine the sample size. A total of 430 questionnaires were distributed to achieve the 312 completely filled questionnaires, hence, the response rate was $73 \%$.

\subsection{Measured variables}

Psychological empowerment was measured using 12 items from Spreitzer (1992, 1995b) based on four dimensions, namely meaning, competence, autonomy and impact. The scores from these dimensions are averaged to form an overall score for psychological empowerment for each respondent. To measure trust, the subscale of trust to principal from the Omnibus T-Scale (Hoy \& Tschannen-Moran, 2003) was used. Four items from the instrument used by Spreitzer (1996) was modified to measure access to information. Five items were modified from the short form of Perceived Organizational Support Scale developed by Eisenberger et. al. (1986) to measure access to organizational support. Three items from Spreitzer (1996) to measure access to resources was modified and two new items were added to include access to teaching materials, equipments, funds, work space and time as resources. Four items from Short and Rinehart (1992) were modified to measure access to opportunity to learn and develop.

The data collected was analyzed using correlation to find out the relationship between variables under study. Regression analysis was also conducted to identify the contribution of each antecedent to psychological empowerment. 


\section{Results and discussion}

\subsection{Verification of psychological empowerment dimensions}

The study verifies that psychological empowerment comprises four dimensions as suggested by Spreitzer (1992). Although the exploratory factor analysis using principal component extraction and varimax rotation with Kaiser Normalization proves that psychological empowerment consists of only three dimensions, the scree test and confirmatory factor analysis shows that it consists of four dimensions with factor loading between .76 and .92. This finding is consistent with those empirical studies of Thomas \& Tymon (1993), Gomez \& Rosen (1994), Sparrowe (1994), Spreitzer (1995b, 1996), Kirkman \& Rosen (1996), and Carless (2004). Therefore, this finding verifies that the scale developed by Spreitzer (1992) can be used in the context of private higher education institution in Malaysia.

To test the internal consistency of each factor or dimension, reliability coefficient of Cronbach Alpha is determined using SPSS software version 15.0. Each factor was found to have sufficient internal consistency with alpha values ranging from .84 to .90 . The value of alpha for meaning, competence, autonomy and impact is $.85, .87, .84$ and .90 accordingly. The alpha value for the overall psychological empowerment is .86 . The alpha values for antecedents range from .82 to .92 . Table 1 below shows the mean and standard deviation for each variable in this study.

\subsection{Relationship of antecedents to psychological empowerment}

Analysis of correlation finds that all antecedents under study have significant relationship with psychological empowerment at .01 significance level. Based on the correlation values, trust, access to information and access to organizational support has a low positive relationship $(\mathrm{r}=.20, .24$ and .26 accordingly) with psychological empowerment while access to resources and opportunity to learn and develop has a moderate positive relationship ( $\mathrm{r}$ $=.34$ and .35 accordingly) with psychological empowerment.

In terms of its dimension, trust does not have any significant relationship with meaning and competence, but has low positive relationship with autonomy $(r=24)$ and impact $(r=.198)$. Access to organizational support also does not have any significant relationship with meaning and competence but has low positive relationship with autonomy $(\mathrm{r}=.21)$ and impact $(\mathrm{r}=.29)$. Access to information has low positive relationship with meaning, autonomy and impact $(\mathrm{r}=.19, .19$ and .23 accordingly) but does not have any significant relationship with competence. Access to resources has moderate positive relationship with autonomy $(\mathrm{r}=.34)$ but low positive relationship with meaning $(\mathrm{r}=.23)$, competence $(\mathrm{r}=.19)$ and impact $(\mathrm{r}=.22)$. Access to opportunity to learn and develop has moderate positive relationship with impact $(\mathrm{r}=.30)$ but has low positive relationship with meaning $(\mathrm{r}=.21)$, competence $(\mathrm{r}=.18)$ and autonomy $(\mathrm{r}=.29)$. All five antecedents under study has significant relationship with the dimensions of autonomy and impact. Table 2 below illustrates the Pearson Correlation Coefficient of the antecedents in relation to the dimensions of psychological empowerment and overall psychological empowerment.

Regression analysis shows that access to opportunity to learn and develop $\left(\mathrm{t}_{311}=3.28, \mathrm{p}<.01\right)$ and access to resources $\left(\mathrm{t}_{311}=2.55, \mathrm{p}<.05\right)$ is significant predictor of psychological empowerment. Access to opportunity to learn and develop is the most important predictor of psychological empowerment $(\beta=.25)$. Therefore, it can be concluded that psychological empowerment is a function of access to opportunity to learn and develop and also access to resources. Trust, access to information and access to organizational support are not significant predictors to lecturers' psychological empowerment. The $\beta$ values $(-.14, .10$ and .01$)$ and $t$ values $(-1.39,1.18$ and .07$)$ show that these factors are not significant at .05 significance level.

This study has proven the validity and reliability of the psychological empowerment scale (Spreitzer, 1992) in the work context of private higher education institutions. This scale defined psychological empowerment as a motivational construct manifested through four cognitive dimensions, i.e. meaning, competence, autonomy and impact (Spreitzer, 1992; 1995a; 1995b). Therefore, high rating in all dimensions is needed to ensure high level of overall psychological empowerment (Lee \& Koh, 2001). First, management ought to evaluate the level of psychological empowerment at their institution to get information on the lecturers' perception about the structure of psychological empowerment. The management should examine each dimension of psychological empowerment and play active role to increase psychological empowerment by focusing on dimensions that are poorly evaluated by lecturers.

The management also should encourage lecturers to work collaboratively to overcome problems or to carry out certain tasks or project to ensure the achievement of the institution's goal and vision. The management can also increase the feeling of autonomy among lecturers by giving them chances to determine their own work schedule at the time of time table preparation. Lecturers should be given freedom to a certain tolerable level to decide the subject or field for them to teach. The implementation of flexible time table could also give lecturers opportunity to determine their working time according to their preferences.

\section{Conclusion}

This study proves the validity and reliability of the psychological empowerment scale developed by Spreitzer (1992) in the work context of private higher education institutions. The result of regression analysis shows that the most 
important predictor for psychological empowerment is access to opportunity to learn and develop $\left(\beta=.25, \mathrm{t}_{311}=3.28\right.$, $\mathrm{p}<.01)$, followed by access to resources $\left(\beta=.20, \mathrm{t}_{311}=2.55, \mathrm{p}<.05\right)$. This study also finds that lecturers are more likely to create new ideas, initiate support and seek endorsement for new ideas, apply and evaluate the use of innovative ideas if they have access to needed strategic information. Therefore, management should create the work environment that is empowering to lecturers by giving lecturers access to opportunity to learn and develop and access to resources.

\section{References}

Bahagian Perancangan dan Penyelidikan Pendidikan. (1995, Jun). Pengupayaan dalam Kementerian Pendidikan: Konsep dan pelaksanaannya. Kuala Lumpur: Kementerian Pendidikan Malaysia.

Brancato, V. (June, 2006). Enhancing psychological empowerment for nurses. The Pennsylvania Nurse. Pennsylvania Nurses Association. p. 31. [Accessed on February 21, 2007]. Accessed from World Wide Web: http: www.panurses.org.

Carless, S. A. (2004). Does psychological empowerment mediate the relationship between psychological climate and job satisfaction? Journal of Business and Psychology, 18(4): 405-425.

Cochran, W. G. (1977). Sampling techniques. ( $3^{\text {rd }}$. ed.). New York: John Wiley \& Sons.

Conger, J. A. \& Kanungo, R. N. (1988). The empowerment process: Integrating theory and practice. Academy of Management Review, 13 (3): 471-482.

Dee, J. R., Henkin, A. B. \& Duemer, L. (2003). Structural antecedents and psychological correlates of teacher empowerment. Journal of Educational Administration, 41(3): 257-277.

Eisenberger, R., Huntington, R., Hutchinson, S. \& Sowa, D. (1986). Perceived organizational support. Journal of Applied Psychology, 71(3): 500-507.

Gomez, C. \& Rosen, B. (1994). The relationship between managerial trust, employee empowerment and employee performance. Working paper. The University of North Carolina at Chapel Hill.

Hancer, M. \& George, R. T. (2003). Psychological empowerment of non-supervisory employees working in full-service restaurants. Hospitality Management, 22: 3 -16.

Hoy, W. K. \& Tschannen-Moran, M. (2003). The conceptualization and measurement of faculty trust in schools: The Omnibut T-Scale in W. K. Hoy \& C. G. Miskel (eds.). Studies in Leading and Organizing Schools (pp. 181-208). Greenwich, CT: Information Age.

Janssen, O. (2000). Job demands, perceptions of effort-reward fairness and innovative work behaviour. Journal of Occupational and Organizational Psychology, 73: 287-302.

Kanter, R. M. (1977). Men and women of the corporation. New York: Basic Books.

Kanter, R. M. (1983). The change masters. New York: Simon \& Schusters.

Kirkman, B. L. \& Rosen, B. (1996). Testing a model of team empowerment: An empirical investigation of antecedents and outcomes of empowered self-managing work teams. Working paper. Universiti of North Carolina at Chapel Hill.

Lee, M. N. N. (1999). Private higher education in Malaysia. Pulau Pinang: School of Educational Studies, Universiti Sains Malaysia.

Lee, M. \& Koh, J. (2001). Is empowerment really a new concept? International Journal of Human Resource Management, 12(4): 684-695.

Lohr, S.L. (1999). Sampling: Design and analysis. Pacific Grove, CA: Duxbury Press.

Marzita Abdullah. (2005, 3 Mac). Kuasa autonomi - Sukar dilakukan di Malaysia. Bernama: Pendidikan Bestari Utusan Malaysia.

Mishra, A. K. \& Spreitzer, G. M. (1994). Building trust and empowerment during industry upheaval. Presented at the Academy of Management Conference, August, Dallas.

Short, P. M. \& Rinehart, J. S. (1992). School Participants Empowerment Scale: Assessment of level of empowerment within the school environment. Journal of Educational and Psychological Measurement, 52: 951-960.

Sparrowe, R. T. (1994). Empowerment in the hospitality industry: An exploration of antecedents and outcomes. Hospitality Research Journal, 17: 51-73.

Spreitzer, G. M. (1992). When organizations dare: The dynamics of psychological empowerment in the workplace. UMI Microform Number 3011067. Ann Arbor: Bell \& Howell Information and Learning Company.

Spreitzer, G. M. (1995a). An empirical test of a comprehensive model of intrapersonal empowerment in the workplace. American Journal of Community Psychology, 23 (5): 601-629. 
Spreitzer, G. M. (1995b). Psychological empowerment in the workplace: Dimension, measurement, and validation. Academy of Management Journal, 38(5): 1442-1465.

Spreitzer, G. M. (1997). Toward a common ground in defining empowerment. Research in Organizational Change and Development, 10: 31-62.

Thomas, K. W. \& Tymon, W. G. (1993). Empowerment inventory. Tuxedo, New York: Xicom.

Thomas, K. W. \& Velthouse, B. A. (1990, October). Cognitive elements of empowerment: An "interpretive" model of intrinsic task motivation. Academy of Management. The Academy of Management Review. 15(4): 666-681.

Zimmerman, M. A. (1990). Taking aim on empowerment research: On the distinction between individual and psychological conceptions. American Journal of Community Psychology, 16: 725-750.

Table 1. Means and Standard Deviations of Variable

\begin{tabular}{lll}
\hline Variable & $\bar{X}$ & SD \\
\hline & & \\
1. Trust & 4.49 & 1.18 \\
2. Access to information & 4.90 & 1.17 \\
3. Access to organizational support & 4.35 & 1.13 \\
4. Access to resources & 4.68 & 1.13 \\
Access to opportunity to learn and develop & 5.08 & 1.04 \\
6. Meaning & 6.34 & 0.79 \\
7. Competence & 6.15 & 0.73 \\
8. Autonomy & 5.59 & 0.97 \\
9. Impact & 4.57 & 1.27 \\
10. Psychological empowerment & 5.66 & 0.68 \\
11. Innovative behavior & 4.70 & 1.16 \\
\hline
\end{tabular}

Table 2. Pearson Correlation Coefficient of Antecedents to Psychological Empowerment

\begin{tabular}{|c|c|c|c|c|c|}
\hline \multirow[b]{2}{*}{ Dimension } & \multicolumn{5}{|c|}{ Psychological Empowerment } \\
\hline & Overall & Meaning & Competence & Autonomy & Impact \\
\hline Trust & $.20(* *)$ & .08 & -.01 & $.24(* *)$ & $.20(* *)$ \\
\hline Access to information & $.24(* *)$ & $.19(* *)$ & .07 & $.19(* *)$ & $.23(* *)$ \\
\hline $\begin{array}{l}\text { Access to organizational } \\
\text { support }\end{array}$ & $.26(* *)$ & .10 & .07 & $.21(* *)$ & $.29(* *)$ \\
\hline Access to resources & $.34(* *)$ & $.23(* *)$ & $.19(* *)$ & $.34(* *)$ & $.22(* *)$ \\
\hline $\begin{array}{l}\text { Access to opportunity to learn } \\
\text { and develop }\end{array}$ & $.35(* *)$ & $.21(* *)$ & $.19(* *)$ & $.29(* *)$ & $.30(* *)$ \\
\hline
\end{tabular}

$* *$ Correlation is significant at .01 levels (2-tails). 